\title{
Measuring Growth in Complex Systems: How Do Growth Regulators Alter Growth?
}

\author{
C.G. Forshey \\ New York State Agricultural Experiment Station, Hudson Valley Laboratory, Highland, NY 12528
}

\section{GENERAL}

The crop of an apple planting is the product of the interaction of two factors: the total production of dry matter per unit of land, and the partitioning of that dry matter between fruit and wood. Yield alone does not adequately describe productive efficiency. The yield must be related to vegetative growth, but, unfortunately, total vegetative growth is difficult to determine. The shoots of an apple tree are conspicuous and easily measured, but they represent only a fraction of the total vegetative growth (Forshey and McKee, 1970; Forshey et al., 1983; Mochizuki, 1962). Root growth and secondary thickening of trunk and scaffold branches account for the major part of the vegetative increment, but measurement of this growth is impractical to impossible. The assessment of growth regulator and other treatment effects is complicated by the lack of a single, simple measure that accurately characterizes vegetative growth (Forshey, 1989; Forshey and Elfving, 1989).

Shoots are the most common index of vegetative growth. While it is often assumed that shoot growth is proportional to total growth, this is not always true. Shoot growth may respond differently to treatment or stress than other parts of the tree, such as trunk or roots (Wilcox, 1937). Shoot growth is generally expressed as mean shoot length, but total shoot growth per tree is more closely related to the number of shoots than to shoot length (Barlow, 1966; Forshey, 1982b, 1989; Forshey and Elfving, 1989; Forshey and Marmo, 1985; Forshey et al., 1983; Quinlan and Preston, 1968). This point is particularly important in the vegetative growth-fruiting relationship because fruiting has a greater effect on shoot number than on shoot length (Avery, 1969, 1970; Forshey, 1982b, 1989; Forshey and Marmo, 1985; Quinlan and Preston, 1968). Total shoot growth per tree is much more meaningful than mean shoot length but is obviously difficult to determine on large trees. Where total shoot growth measurements are practical, relating yield to shoot growth (kilograms of fruit per meter of shoot growth) provides an index of the vegetative growth-fruiting relationship (Forshey, 1982b; Forshey and Elfving, 1989). These values vary widely with cultivar and growth habit (Table 1) and are, therefore, more useful as indicators of change than as specific goals.

The leaf canopy is a reflection of the vegetative growth-fruiting relationship (Forshey, 1989; Forshey and Elfving, 1989). It is comprised of varying proportions of shoot and spur leaves. If extremes are avoided, cultural practices have little or no short-term effect on total leaf are per tree, but may result in substantial changes in the relative proportions of shoot and spur leaves (Barlow, 1964; Forshey and Marmo, 1985; Lakso, 1984; Palmer and Jackson, 1977). Total shoot leaf area is closely associated with total shoot growth, total spur leaf area is closely associated with fruitfulness, and the two (shoot leaf area and spur leaf area) are inversely related (Forshey, 1989; Forshey and Elfving, 1989; Forshey and Marmo, 1985; Forshey et al., 1983). If total leaf area per tree is determined and

Table 1. Relationship between yield of fruit and shoot growth of spur type and nonspur 'McIntosh' apple trees (Peru, N.Y.).

\begin{tabular}{lcc}
\hline \hline & \multicolumn{2}{c}{$\mathrm{kg}$ of fruit/m of shoot growth } \\
\cline { 2 - 3 } Year & Spur type & Nonspur \\
\hline $1984^{z}$ & $1.38^{* *}$ & 0.78 \\
1985 & $1.92^{* *}$ & 1.02 \\
$1986^{y}$ & $0.91^{* *}$ & 0.27 \\
1987 & $1.56^{* *}$ & 0.62 \\
Mean & $1.37^{* *}$ & 0.60 \\
\hline
\end{tabular}

${ }^{2}$ Trees were 8 years old in 1984 .

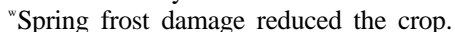

**Significantly different at $P=0.01$ by $t$ test. Comparisons are within years only. 
the relative proportions of shoot and spur leaves are calculated, the percentage of shoot leaves is positively related to total shoot growth and negatively related to yield (Table 2). This single statistic is, therefore, an expression of both vegetative growth and of fruitfulness. Changes in the percentage of shoot leaves indicate changes in the vegetative growth-fruiting relationship (Forshey and Elfving, 1989). Since the number of shoot leaves and spur leaves is inversely related, changes in the percentage of spur leaves, or in the ratio of spur leaves : shoot leaves, similarly indicate changes in the vegetative growth-fruiting relationship. The relative proportions of shoot and spur leaves vary with cultivar, growth habit, vigor, pruning, and crop (Ferree and Forshey, 1988; Forshey and Marmo, 1985; Forshey et al., 1983, 1987; Lakso, 1984; Palmer and Jackson, 1977; Table 3). As with kilograms of fruit per meter of shoot growth, measures of the relative proportions of shoot and spur leaves are more valuable as indicators of change in the vegetative growthfruiting relationship than as specific goals.

The relationship between leaf area and crop load is often characterized by the leaf : fruit ratio, that is, the average number of leaves per fruit (Ferree and Cahoon, 1987; Ferree and Palmer, 1982; Hansen, 1969; Jones and Samuelson, 1983; Magness and Overley, 1930; Shen, 1941). However, the nature of the canopy, with varying proportions of shoot and spur leaves, suggests that this simple numerical ratio may be inadequate. In general, shoot leaves are $\approx 50 \%$ larger than spur leaves (Forshey and Elfving, 1989; Forshey and Marmo, 1985; Forshey et al., 1983). While it is clear that spur leaves are dominant during flower development, fruit set, and early fruit growth (Arthey and Wilkinson, 1964; Hansen, 1971, 1977; Llewelyn, 1963, 1966, 1968), there is increasing evidence to indicate that the shoot leaves contribute more to fruit growth after

Table 2. Correlation of percent shoot leaves with yield or shoot growth of 'McIntosh' apple trees (Peru, N.Y.).

\begin{tabular}{llr}
\hline \hline Year & Percent shoot leaves with: & \multicolumn{1}{c}{$r$} \\
\hline $1984^{2}$ & Yield/tree & $-0.80^{* *}$ \\
& Total shoot growth/tree & $0.86^{* *}$ \\
1985 & Yield/tree & $-0.88^{* *}$ \\
& Total shoot growth/tree & $0.82^{* *}$ \\
1986 & Yield/tree & $-0.83^{* *}$ \\
& Total shoot growth/tree & $0.80^{* *}$ \\
\hline
\end{tabular}

${ }^{2}$ Trees were 8 years old in 1984 .

** Statistically significant at $P=0.01$.

Table 3. Effects of pruning and growth habit on the percentage of shoot leaves of three apple cultivars (Hudson Valley, N.Y., 1988).

\begin{tabular}{llc}
\hline \hline Cultivar & \multicolumn{1}{c}{ Variable } & $\begin{array}{c}\text { Shoot leaves, \% } \\
\text { total leaf area }\end{array}$ \\
\hline Empire & Conventional pruning & 14.1 \\
& Extensive heading-back & $39.5^{*}$ \\
Starkrimson Delicious & Conventional pruning & 8.5 \\
& Spur pruning & $14.8^{*}$ \\
McIntosh (nonspur) & Thinning-out pruning & 39.2 \\
& Heading-back pruning & $57.1^{*}$ \\
McIntosh & Spur type growth habit & 20.0 \\
& Nonspur growth habit & $49.8^{*}$ \\
\hline
\end{tabular}

*Significantly different at $P=0.05$ by $t$ test.

Table 4. Effects of $\mathrm{BA}^{2}$ applications on shoot growth and relative proportion of shoot leaves of 'Empire' apple trees (Germantown, N.Y., 1984).

\begin{tabular}{lcc}
\hline \hline $\begin{array}{l}\mathrm{BA} \\
\begin{array}{c}\text { concn } \\
(\mathrm{ppm})\end{array}\end{array}$ & $\begin{array}{c}\text { No. shoots/cm } \\
\text { branch } \\
\text { circumference }\end{array}$ & $\begin{array}{c}\text { Shoot leaves, } \\
\% \text { total } \\
\text { leaf area }\end{array}$ \\
\hline 0 & 0.80 & 14.7 \\
50 & 1.04 & 17.9 \\
150 & 1.36 & 22.8 \\
450 & 1.89 & 30.1 \\
Coefficient of & & $0.84^{* *}$ \\
\multicolumn{1}{c}{ correlation" } & $0.81^{* *}$ &
\end{tabular}

${ }^{\prime} N$-(phenylmethyl)1 $\quad H$-purin-6-amine.

${ }^{y}$ All applications 1 week after petal fall.

'Correlation with BA concentration. midsummer than the spur leaves (Myers and Ferree, 1983; Rom and Ferree, 1986; Van der Boon, 1980; Watson, et al., 1978). In fact, the consistent poor fruit size associated with spur-bound trees may be due in large part to the lack of shoot leaves. With established differences between shoot and spur leaves in both size and physiological activity, it would be more descriptive to express the ratio as leaf area per fruit, and to supplement this with a determination of the relative proportions of shoot and spur leaves.

\section{GROWTH REGULATORS}

Growth regulators such as damidozide, ethephon, chlormequat, and paclobutrazol may dramatically reduce shoot growth (Batjer et al., 1964; Edgerton and Hoffman, 1965; Forshey, 1970; Greene and Lord, 1978; Luckwill, 1968, 1970; Miller, 1988; Quinlan, 1981; Southwick et al., 1965; Steffins et al., 1983; Stinchcombe et al., 1984; Sweitlik and Miller, 1983; Volz and Knight, 1986; Williams, 1972). The response varies with chemical, application rate, timing, cultivar, and vigor. Appropriate treatments may reduce mean shoot length by one-third to one-half. With respect to leaf area, this can be somewhat deceptive. The reduction in shoot growth may be largely due to reduced internode length with relatively little effect on the number of shoot leaves or their size (Filipovich and Rowe, 1977). As a result, the effect on total shoot leaf area may be proportionately less than the effect on shoot growth. A growth regulator-induced reduction in shoot growth is often followed by increased flowering the next year (Luckwill, 1970, 1974; Mika et al., 1983; Miller, 1988; Quinlan and Preston, 1978; Volz and Knight, 1986; Williams, 1972). This response may be useful in encouraging earlier commercial fruit production in strongly vegetative, sparingly fruitful young trees (Batjer et al., 1964; Miller, 1988; Williams, 1984). The response is reflected in corresponding changes in the relative proportions of shoot and spur leaves. However, effective shoot growth control does not always increase flowering, and flowering is sometimes increased with little or no reduction in shoot growth (Batjer et al., 1964; Green and Lord, 1978; Looney and Kamienska, 1978; Luckwill, 1970; Tromp, 1972, 1973). As a result, reduced shoot growth and increased flowering the following year may be frequently associated, but are not necessarily directly related (Batjer et al., 1964; Luckwill, 1970; Tromp, 1972, 1973; Tromp and Wertheim, 1980). In contrast to growth retardants, chemicals such as BA may increase shoot growth and shoot leaf area (Table 4). Appropriate rates and timing of BA can stimulate branching in cultivars that characteristically make limited lateral growth. This is useful in improving the structure and increasing the bearing surface of young trees (Elfving, 1984; Forshey, 1982a; Miller, 1988; Quinlan and Preston, 1978). Other possible effects include paclobutrazol-induced reductions in leaf size with the spur leaves affected more than the shoot leaves (Greene and Murray, 1983; Steffins et al. 1983). Conversely, gibberellins may increase leaf size (Greene and Murray, 1983; Williams, 1984).

Growth regulators can obviously affect the leaf canopy in various ways. Significant changes in shoot growth, either increases or decreases, or in flowering can alter the leaf canopy quantitatively and/ or qualitatively.

\section{Literature Cited}

Arthey, V.D. and E.H. Wilkinson. 1964. The effect of preblossom defoliation on the cropping of Cox's Orange Pippin apple. Hort. Res. 4:2226.

Avery, D.J. 1969. Comparisons of fruiting and deblossomed maiden apple trees, and of non-fruiting trees on a dwarfing and an invigorating rootstock. New Phytol. 68:323-336.

Avery, D.J. 1970. Effects of fruiting on the growth of apple trees on four rootstock varieties. New Phytol. 69:19-30.

Barlow, H.W.B. 1964. An interim report on a long-term experiment to assess the effect of cropping on apple tree growth. Annu. Rpt. E. Malling Res. Sta. 1963, p. 84-93.

Barlow, H.W.B. 1966. The effect of cropping on the number and kind of shoots on four apple varieties. Annu. Rpt. E. Malling Res. Sta. 1965, p. $120-124$.

Batjer, L.P., M.W. Williams, and G.C. Martin. 1964. Effects of N-dimethyl amino succinamic acid (B-Nine) on vegetative and fruit charac- 
teristics of apples, pears, and sweet cherries. Proc. Amer. Soc. Hort. Sci. 85:11-16.

Edgerton, L.J. and M.B. Hoffman. 1965. Some physiological responses of apples to $\mathrm{N}$-dimethyl amino succinamic acid and other growth regulators. Proc. Amer. Soc. Hort. Sci. 86:28-36.

Elfving, D.C. 1984. Factors affecting apple-tree response to chemical branch induction treatments. J. Amer. Soc. Hort. Sci. 109:476-481.

Ferree, D.C. and G.A. Cahoon. 1987. Influence of leaf to fruit ratios and nutrient sprays on fruiting, mineral elements, and carbohydrates of apple trees. J. Amer. Soc. Hort. Sci. 112:445-449.

Ferree, D.C. and C.G. Forshey. 1988. Influence of pruning and urea sprays on growth and fruiting of spur-bound 'Delicious' apple trees, J. Amer. Soc. Hort. Sci. 113:699-703.

Ferree, D.C. and J.W. Palmer. 1982. Effect of spur defoliation and ringing during bloom on fruiting, fruit mineral level, and net photosynthesis of 'Golden Delicious' apple. J. Amer. Soc. Hort. Sci. 107:1182-1186.

Filipovich, S.D. and R.N. Rowe. 1977. Effect of succinic acid 2,2-Dimithyl hydrazide $(\mathrm{SADH})$ on starch accumulation in young apple trees. J. Hot? Sci. 52:367-370.

Forshey, C.G. 1970. The use of Alar on vigorous 'McIntosh' apple trees. J. Amer. Soc. Hort. Sci. 95:64-67.

Forshey, C.G. 1982a. Branching responses of young apple trees to applications of 6-benzylamino purine and gibberellin $\mathrm{A}_{4+7}$. J. Amer. Soc Hort. Sci. 107:.538-541.

Forshey, C.G. 1982b. Effects of fruiting, pruning, and nitrogen fertilization on shoot growth of 'Empire' apple trees. J. Amer. Soc. Hort. Sci. 107:10921097 .

Forshey, C.G. 1989. Measuring the effects of growth regulators on the vegetative growth-fruiting relationship in apple trees. Acta Hort. 239:211219

Forshey, C.G. and D.C. Elfving. 1989. The relationship between vegetative growth and fruiting in apple trees. Hort. Rev. 11:229-287.

Forshey, C.G. and M.W. McKee. 1970. Production efficiency of a large and a small 'McIntosh' apple tree. HortScience 5:164-165.

Forshey, C.G. and C.A. Marmo. 1985. Pruning and deblossoming effects on shoot growth and leaf area of 'McIntosh' apple trees. J. Amer. Soc. Hort. Sci. 110:128-132.

Forshey, C.G., R.W. Weires, B.H. Stanley, and R.C. Seem. 1983. Dry weight partitioning of 'McIntosh' apple trees. J. Amer. Soc. Hort. Sci. 108:149-154.

Forshey, C.G., R.W. Weires, and J.R. VanKirk. 1987. Seasonal development of the leaf canopy of 'Macspur McIntosh' apple trees. HortScience 20:881-883.

Greene, D.W. and W.J. Lord. 1978. Evaluation of scoring, limb spreading and growth regulators for increasing flower bud initiation and fruit set on young 'Delicious' apple trees. J. Amer. Soc. Hort. Sci. 103:208-210.

Greene, D.W. and J. Murray. 1983. Effect of paclobutrazol (PP 333) and analogs on growth, fruit quality and storage potential of 'Delicious' apples. Plant Growth Regulat. Soc. Amer. 10:207-212.

Hansen, P. 1969. ${ }^{14} \mathrm{C}$ studies on apple trees. IV. Photosynthate consumption in fruits in relation to the leaf-fruit ratio and to the leaf-fruit position. Physiol. Plantarum 22:186-198.

Hansen, P. 1971. ${ }^{14} \mathrm{C}$ studies on apple trees. VII. The early season growth in leaves, flowers and shoots as dependent upon current photosynthates and existing reserves. Physiol. Plantarum 25:469-473.

Hansen, P. 1977. Carbohydrate allocation, p. 247-258. In: J.J. Landsberg and C.V. Cutting (eds.). Environmental effects on crop physiology. Academic, London.

Jones, H.G. and T.J. Samuelson. 1983. Calcium uptake by developing apple fruit: II. The role of sour leaves. J. Hort. Sci. 58:183-190.

Lakso, A.N. 1984. Leaf area development patterns in young pruned and unpruned apple trees. J. Amer. Soc. Hort. Sci. 109:861-865.

Llewelyn, F.W.M. 1963. The importance of spur leaves and lime-sulphur sprays on fruit retention in three apple varieties. Annu. Rpt. E. Malling Res. Sta. 1962, p. 89-92.

Llewelyn, F.W.M. 1966. The results of three years ${ }^{9}$ spray and defoliation treatments, and their residual effects, on fruit retention in three apple varieties. Annu. Rpt. E. Malling Res. Sta. 1965, p. 125-127.

Llewelyn, F.W.M. 1968. The effect of partial defoliation at different times in the season on fruit drop and shoot growth in Lord Lambourne apple trees. J. Hort. Sci. 43:519-526.

Looney, N.E. 1969. Importance of time and concentration of annual applications of succinic acid 2,2-dimethyl hydrazide (Alar) to pome fruits Can. J. Plant Sci. 49:489-494.
Looney, N.E. and R.L. Kamienska. 1978. Metabolism of ${ }^{3} \mathrm{H}$ gibberellin A in relation to flower initiation in apple. Acta Hort. 80:105-111.

Luckwill, L.C. 1968. The effect of certain growth regulators on growth and apical dominance of young apple trees. J. Hort. Sci. 43:91-101.

Luckwill, L.C. 1970. The control of growth and fruitfulness of apple trees, p. 237-254. In: L.C. Luckwill and C.V. Cutting (eds.). Physiology of tree crops. Academic, New York.

Luckwill. L.C. 1974. A new look at the process of fruit bud formation in apple. Proc. XIXth Intl. Hort. Congr. 3:237-245.

Magness, J.R. and F.L. Overley. Relation of leaf area to site and quality of apples and pears. Proc. Amer. Soc. Hort. Sci. 26:160-162.

Mika, A., M.J. Grochowska, A. Karaszewska, and M.W. Williams. 1983. Effects of dormant and summer pruning, disbudding, and growth retardants on growth, flower bud formation, and fruiting of young apple trees. J. Amer. Soc. Hort. Sci. 108:655-660.

Miller, S.S. 1988. Use of plant bioregulators in apple and pear culture. Hort. Rev 10:309-401.

Mochizuki, T. 1962. Studies on the elucidation of factors affecting the decline in tree vigor as induced by fruit load. Bul. Fac. Agr. Hirosaki Univ. 8:40-124.

Myers, S.C. and D.C. Ferree. 1983. Influence of time of summer pruning and limb orientation on yield, fruit size, and quality of vigorous 'Delicious' apple tress. J. Amer. Soc. Hort. Sci. 108:630-633.

Palmer, J.W. and J.E. Jackson. 1977. Seasonal light interception and canopy development in hedgerow and bed system apple orchards. J. Applied Ecol. 14:539-549.

Quinlan, J.D. 1981. New chemical approaches to the control of fruit tree form and size. Acta Hort. 120:95-106

Quinlan, J.D. and A.P. Preston. 1968. Effects of thinning blossom and fruitlets on growth and cropping of Sunset apple. J. Hort. Sci. 43:373 381

Quinlan, J.D. and A.P. Preston. 1978. The use of branching agents to replace hand pruning of young trees of Bramley's Seedling apple. J. Hort. Sci. 53:39-43.

Rom, C.R. and D.C. Ferree. 1986. The influence of fruiting and shading of spurs and shoots on spur performance. J. Amer. Soc. Hort. Sci. 111:3.52 356.

Shen, T. 1941. The influence of leaf-fruit ratio on alternate bearing in the apple. Proc. Amer. Soc. Hort. Sci. 38:127-132.

Southwick, F.W., W.J. Lord, W.D. Weeks, G.W. Olanyk, and A.W. Rossi. 1965. Preliminary studies concerning the influence of B-995 on flesh firmness, red color, water core and the growth rate of apples. Annu. Rpt. Mass. Fruit Growers Assn. 71:36-40.

Steffins, G.L., S.Y. Yang, C.L. Steffins, and T. Brennan. 1983. Influence of paclobutrazol (PP333) on apple seedling growth and physiology. Proc 10th Annu. Mtg. Plant Growth Regulat. Soc. Amer., p. 195-206.

Stinchcombe, G.R., E. Copas, R.R. Williams, and G. Arnold. 1984. The effects of paclobutrazol and daminozide on the growth and yield of cide apple trees. J. Hort. Sci. 59:323-327.

Swietlik, D. and S.S. Miller. 1983. The effect of paclobutrazol on growth and response to water stress of apple seedlings. J. Amer. Soc. Hort. Sci. 108:1076-1080.

Tromp, J. 1972. Effects of growth-regulating substances and tree orientation on growth and flower-bud formation in apple. J. Hort. Sci. 47:525-533.

Tromp, J. 1973. The interaction of growth regulators and tree orientation on fruit-bud formation. Acta Hort. 34:185-188.

Tromp, J. and S.J. Wertheim. 1980. Synthetic growth regulators: Mode of action and application in fruit production. Proc. 15th Colloq. Intl. Potash Inst. p. 137-150.

Van der Boon, J. 1980. Prediction and control of bitter pit in apples. II. Control by summer pruning, fruit thinning, delayed harvesting and soil calcium dressing. J. Hort. Sci. 55:313-321.

Volz, R.K. and J.N. Knight. 1986. The use of growth regulators to increase precocity in apple trees. J. Hort. Sci. 61:181-189.

Watson, R.L., J.J. Landsberg, and M.R. Thorpe. 1978. Photosynthetic characteristics of the leaves of 'Golden Delicious' apple trees. Plant Cell \& Env. 1:51-58.

Wilcox, J.C. 1937. Field studies of apple tree growth and fruiting. III. Some observations on the measurement of tree vigor. Sci. Agr. 17:657-669.

Williams, M.W. 1972. Induction of spur and flower bud formation in young apple trees with chemical growth retardants. J. Amer. Soc. Hort. Sci. 97:210-212.

Williams, M.W. 1984. Use of bioregulators to control vegetative growth of fruit trees and improve fruiting efficiency. Acta Hort. 146:97-104. 